\title{
Opting for a Controlled-Firm Majority Independent Directors Exemption to NYSE or NASDAQ Listing Requirements: Much Ado about Nothing?
}

\author{
Jeffery A. Born ${ }^{1}$ \\ ${ }^{1}$ Finance Group, D'Amore-McKim School of Business, Northeastern University, Boston, USA \\ Correspondence: Jeffery A. Born, Professor of Finance, D'Amore-McKim School of Business, Northeastern \\ University, Boston, Massachusetts, USA.
}

Received: November 20, 2015

Accepted: December 9, $2015 \quad$ Online Published: January 19, 2016

doi:10.5430/ijfr.v7n1p195

URL: http://dx.doi.org/10.5430/ijfr.v7n1p195

\begin{abstract}
The behavior of controlled-firms that opt out of the requirement that the majority of their Board members be independent is contrasted against controlled-firms who conformed to requirement in the ten year period 2005-2014. The Boards and management structure of these exempt and non-exempt controlled firms are remarkably similar. We find exempt firms have on average smaller market values, but use more debt, hold less cash, make larger investments in intangible assets, spend more on $\mathrm{R} \& \mathrm{D}$, and have a more efficient workforce that grows slower than non-exempt controlled firms. This pattern of behaviors is more consistent with a stewardship hypothesis. We find strong evidence that investors substantially increase the $\mathrm{Q}$ ratios of family and founder-controlled firms. We find weak evidence that obtaining a controlled-firm exemption reduces $Q$ values, but these reductions are small compared with the reductions in $\mathrm{Q}$ values associated with adopting take-over barriers. We conclude the fear that many large firms seem to have over seeking an exemption may not be well founded.
\end{abstract}

Keywords: controlled-firm, independent director, board composition

\section{Introduction}

In response to a host of major corporate accounting scandals (e.g. Enron, Tyco, WorldCom), the US Congress enacted, and President George W. Bush signed into law, the Sarbanes-Oxley Act of 2002 (SOX). This legislation sought to restore confidence in US Securities Markets and the audited statements issued by public firms. The Act empowered the SEC to propose rules that would implement reforms contained in SOX. Beginning with rules designed to ensure that a majority of the Board of Director members of the Audit Committee were 'independent', the SEC subsequently ruled in 2003 that a majority of the Board itself should be independent. (Note 1, Note 2)

In March of 2003 the NYSE and NASDAQ proposed changes to their requirements for listed firms requiring a majority of the Board of Directors be independent. On November 4, 2003 the SEC accepted the changes proposed by the NYSE and NASDAQ. Publically-listed firms essentially had to comply with these new requirements no later than 2005. Both the NYSE and NASDQ provide that a firm may opt for an exemption to this requirement if "any individual or group of shareholders control more than $50 \%$ of the company's shares." Under Rules $13 \mathrm{~d}-3$ and 13d-5(b)(1) of the Exchange Act of 1940, a "group" is deemed to exist when "two or more persons agree to act together for the purposes of acquiring, holding, voting, or disposing of equity securities of an issuer." Whilst the NYSE and NASDAQ have slightly different methods of operationalizing the definition of a 'group' they are in agreement that $50 \%$ applies to voting power in the case of multi-class companies, when the share classes have different voting rights/power.

Whilst the NYSE and NASDAQ provide for an exemption, firms that meet the control threshold are not required to take an exemption and a number of controlled-firms on each exchange have not. (Note 3) Even controlled-firms that opt for the exemption can have a large number, even a majority of their directors be deemed independent. The vast majority of controlled-firms that opt for the exemption report the number of independent Board members to their shareholders in the proxy statement.

Of interest is whether the behavior of firms that opt for the exemption differ from the behavior of otherwise 'controlled-firms' that do not opt for the exemption. Controlled-firms that do not seek an exemption must have a majority of their Directors be independent - exempt controlled-firms can choose to have no independent Directors. 
We investigate whether the (potential) difference in Board structures translates into difference(s) in behavior. We also examine the role of other factors, such as the identity of the controlling individual/group (family, founder, stakeholder, company/hedge-fund), whether there is a wedge between the voting power of the controlling group and its ownership position, the existence of anti-takeover mechanisms, whether the controlling individual/group serves as the $\mathrm{CEO}$ and/or as the Board Chair, etc. in explaining differences in controlled-firm behavior.

\section{Relevant Literature}

The managers of 'controlled firms' are insulated from the threat of a change in control (unless it is initiated by the controlling individual or group) unlike their counterparts in 'independent' firms. Managers of controlled firms would be expected to pursue policies consistent with the wishes of the individual/group who have control. These policies could be consistent with shareholder wealth maximization, or other theories. (Note 4) The extent to which the policies of controlled firms differ from shareholder wealth maximizing firms may depend on the individual/group that is in control and the difference between controlling individual/group's voting and ownership percentages.

There is a substantial literature in finance that has focused on the agency problems that can arise when there is a wedge between the amount of control that a manager can exercise over the firm and their economic exposure (through ownership and/or compensation contracts) to the cost of that activity. The exploitation theory argues that managers, when shielded from discipline by shareholders, will engage in activities that maximize their personal welfare at a fraction ( $\alpha$, which is their ownership position) of the cost to the firm. One can argue that as the size of the wedge between ownership and control increases, the more likely exploitive behavior / expropriation is to occur.

Potentially offset the power that sitting management has to direct the resources of the firm, can be the presence of other large stakeholders. If the large stakeholder's private benefit from monitoring the behavior of management exceeds their private cost, their presence would be expected to deter managers from engaging in activities that do not maximize shareholder wealth. However, the potential discipline provided by large stakeholders is blunted when the firm is over $50 \%$ controlled.

Jensen and Meckling (1976) argue that debt (service payments) can reduce the agency problems that can arise when ownership and management are separated. One would expect that the more debt that is used the less likely the controlled-firm would be to engage in expropriating behaviors. The better behavior could be the result of debt service costs which reduce free cash-flow available to the controlling individual/group and/or due to restrictive covenants put in place as a condition for receiving debt financing. However, in the absence of (potential) discipline in controlled-firms, borrowing increases the amount of funds available for non-wealth maximizing activities.

The identity of the individual/group that has the controlling interest may impact the policies of the firm. There is also a substantial literature in the family business field that focuses on the benefits that can arise when control is vested in a multi-generational group (i.e. the 'family'). The stewardship hypothesis posits that when a 'leader[s]' (not necessarily the manager) reputation has a strong past, present and future ties to the reputation of the firm, they have a much longer horizon than those who do not have these ties. The stewardship hypothesis implies that 'family' interests seek to maximize the expected longevity of their association with the firm, perhaps at the expense of current shareholder wealth. However, off-setting the potential benefits of stewardship are the costs that can arise when multiple generations are involved in the leadership of the organization and when control is passed from one generation to another.

Likewise, there is empirical evidence to suggest that the behavior of family controlled firms is dependent upon whether the founder or subsequent generations are in charge. (Note 5) The size of the wedge between the controlling interests (votes) and their economic interests is also likely to impact the extent to which behavior will deviate from the prediction of shareholder wealth maximization. (Note 6) There is rather significant variance in what constitutes or defines a 'family' interest.

There is also evidence to suggest that if the control group is another firm, as opposed to an individual or familial group, its behavior/financial policies may be impacted. Atanasov, Boone and Haushalter (2010) report that parent companies behave opportunistically toward their publically-traded subsidiaries when their ownership share is sufficient to control but below the level of consolidation (50\%). Expropriation of the target is further encouraged when the managers of parent firm have compensation contracts that reward accounting, rather than shareholder performance. 
In summary, there are a range of behaviors that could be observed for controlled-firms. What is lacking is a theoretical motivation for why the behavior of a controlled firm that has chosen an exemption to the US stock exchanges' requirement that the majority of its Board of Directors be independent should be different from the behavior of a controlled firm that has not chosen to obtain an exemption. Although the majority of the Board of a non-exempt controlled firm are 'independent' the controlling individual/group can move for an exemption at any time and replace any/all Directors that do not support their view(s) on the policies the firm should adopt, the managers who should be in charge, etc. It is an empirical question as to whether exempt and non-exempt policies and behavior substantively differ.

\section{Research Design, Variables and Definitions}

We define a firm as 'controlled' in accordance with SEC definition: when one (or more 'connected') individual has the ability to cast $50 \%$ plus one vote. We also include a small number of firms where the controlling individual or group has the ability to elect or appoint the majority of the Board of Directors without necessarily having $50 \%$ plus one vote. (Note 7)

We differentiate the controlling individual or group into one of four ownership types: family, founder, stakeholder, or corporation/hedge fund. For our purposes, we will consider an organization to be under 'family' control or influence when two or more individuals with a familial relationship are employed by the organization in management positions and/or are serving as members of the Board of Directors. We consider an organization to be 'founder' control or influence when the individual who has the controlling position is the original founder of the firm (or part of the founding group). (Note 8) An organization that is controlled or influenced by an individual or a small group of individuals (without a familial relationship), who have not included any family members in key management positions and who have not yet announced plans to transfer their ownership stake(s) to family members are referred to as stakeholder-controlled. These individuals are referred to as 'stakeholders'. Lastly, some firms are controlled or influenced by other publically traded companies and or by hedge funds.

We classify a firm as receiving an exemption to NYSE or NASDAQ independent director requirements in their 2010 fiscal year. The vast majority of firms that applied for an exemption in 2010 has maintained an exemption since there was a change in control event and/or 2004. Centering our analysis on 2010 we gathered ten years of financial and accounting data on either side of that date: 2005-2014 (nine years in total). This time period includes the so-called Great Recession (Note 9) and a substantial post-recovery period. The period of analysis begins with 2005 - the fiscal year by which all public firms either had to have a majority of independent directors or claim a controlled-firm exemption.

We examine the behavior of a number of financial market and accounting measures of performance that have traditionally been employed as surrogates for key financial policies of the firm. We examine firm's debt usage, growth measures and expectations, research \& development/innovation investments, capital expenditures, cash holdings, dividend and (net) share repurchases, profitability, employee efficiency and employment growth. We also examine the firms' use of staggered Board elections, the independence of the CEO and/or Chairman of the Board, whether there is a change in control payment to managers, the existence of non-controlling stakeholders with $5 \%$ ownership stakes, and the wedge between the controlling individual/groups voting and ownership percentages. We test whether controlled firms which have obtained an exemption behaved differently from those who did not during our sample period.

\section{Sample Characteristics and Empirical Results}

We identify 173 firms that qualified for controlled-firm status in fiscal 2010. Of those 120 claimed an exemption and 53 did not. Table 1 reports sample statistics for a variety of aspects of control, Board composition, management structure and anti-takeover provisions. We also report t-statistics from tests of the hypothesis that the mean of an item is equal for exempt and non-exempt firms. 
Table 1. Controlled firms: Exempt and no-exemption

Voting control, ownership, 'Wedge' percentage, management structure, and anti-takeover provisions

\begin{tabular}{lllll}
\hline Item & Exempt & No-Exemption & t-Statistic & Sig. Level \\
\hline Voting Control (mean \%) & 69.63 & 65.75 & 1.534 & .127 \\
Ownership (mean \%) & 53.11 & 48.99 & 1.504 & .293 \\
"Wedge" (voting\% - own\%) & 16.51 & 16.76 & -0.059 & .953 \\
CEO Independent & $23 / 120$ & $12 / 53$ & -0.522 & .602 \\
CEO = Board Chair & $41 / 120$ & $18 / 53$ & 0.026 & .979 \\
Board Chair Independent & $16 / 120$ & $9 / 53$ & -0.626 & .532 \\
Change in Control Payment & $48 / 120$ & $16 / 53$ & 1.230 & .220 \\
Staggered Board Elections & $100 / 120$ & $44 / 53$ & -0.083 & .934 \\
Multiple Class of Stock & $50 / 120$ & $23 / 53$ & -0.102 & .919 \\
Board Seats (mean) & 9.61 & 9.64 & 0.032 & .975 \\
Independent Board Percentage & 0.525 & 0.681 & 16.107 & .000 \\
5\% Owners (mean) & 2.69 & 3.11 & -1.524 & .129 \\
\hline
\end{tabular}

The individual/group that controls firms that seek an exemption to the majority Independent Director requirement on average have more voting power than the individual/group that does not seek an exemption, but the difference is not significant at normal levels. Likewise, there is no difference in their average ownership position, or 'wedge' (voting $\%$ - ownership \%). The ability to create a wedge between one's voting control and ownership position in this sample arises due to the existence of multiple voting securities, one or more of which is endowed with enhanced voting power compared with the other securities issued by the firm. In the extreme, voting power is limited to one issue and other securities are provided no voting power. (Note 10) There is no difference between the two groups in the proportion of firms with multiple classes of stock. There is also no difference in the use of staggered Board member elections across the two groups (both are 'high' $83 \%$ and $79 \%$ for exempt and non-exempt firms, respectively).

Firms seeking an exemption from the majority independent Directors requirement are less likely to have a Board Chair who is independent (Note 11) of the controlling individual/group, but the difference in proportions is not statistically significance at normal levels. Likewise, exempt firms are less likely to have an independent CEO, but the result is not significant. Thus, firms that do not seek an exemption offer the appearance of greater managerial independence from the individual/group that has control. (Note 12) Interestingly, firms that seek an exemption provide their CEO change in control compensation contract more frequently than firms without an exemption and a majority ( 25 of the 48 awards) of exempt-firm CEOs who obtain this benefit are not independent of the controlling individual/group.

There is surprising little difference in the average composition of the Board of Directors for the two groups. Both exempt and non-exempt controlled-firms have a Board of approximately 9 members, with exempt firms have an average of 6.5 independent Directors (as would be necessary to have a majority), whereas the firms claiming an exemption to the majority independent Directors requirement report an average of 5 independent Directors. As a proportion of total seats, independent Directors hold $52.5 \%$ of seats at exempt firms - when technically none are required of these firms. The vast majority of these independent Directors sit on the exempt controlled-firm Auditing, Compensation, and/or Nominating Committees. Independent Directors hold $68 \%$ of the seats for controlled-firms that do not seek an exemption. The difference in proportions is highly significant.

Lastly we note that there are a surprising number of 'independent' individuals/groups (usually mutual fund families) who hold 5\% ownership positions in controlled firms - whether they have sought an exemption or not. Controlled-firms that do not seek an exemption have a slightly larger average number of 'independent' stakeholders than controlled-firms that do seek an exemption. Given the generally negative manner in which controlled-firms are described in the academic literature and the threat of that the firm might engage in behavior that is not shareholder wealth maximizing, the fact that informed investors are taking large ownership positions suggests that they view the threat of 'bad' behavior as rather minimal. 
We report a variety of operating and financial measures plus t-statistics/significance level for tests of the hypothesis that the means of the two groups are equal in Table 2. The first three items are various measures of size: total assets, total revenues, and market value of common equity. We find that controlled-firms that do not seek an exemption to the majority independent Board requirement are significantly larger than those that do seek an exemption. There are a variety of hypotheses that might explain why the largest controlled-firms do not seek exemptions. What is not clear is whether opting to not seek an exemption is shareholder wealth enhancing.

Table 2. Controlled firms

Mean, median and standard deviation of performance and policy measures

\begin{tabular}{lllll}
\hline Item & $\mathrm{N}$ & Mean & Median & Standard Deviation \\
\hline Total Assets & 1634 & $\$ 3,099.4 \mathrm{~K}$ & $\$ 899.6 \mathrm{~K}$ & $\$ 7,333.2 \mathrm{~K}$ \\
Total Revenue & 1643 & $\$ 2,181.9 \mathrm{~K}$ & $\$ 789.0 \mathrm{~K}$ & $\$ 3,495.8 \mathrm{~K}$ \\
Market Value of Equity & 1594 & $\$ 4,452.6 \mathrm{~K}$ & $\$ 741.5 \mathrm{~K}$ & $\$ 19,229.5 \mathrm{~K}$ \\
& & & & \\
LT Debt/Total Assets & 1634 & 0.2930 & 0.1822 & 0.5652 \\
LT Debt/MV Equity & 1593 & 1.8484 & 0.1712 & 29.5729 \\
& & & & \\
R\&D/Total Assets & 691 & 0.0805 & 0.0086 & 0.1451 \\
R\&D/Employee & 660 & $\$ 28.96 \mathrm{~K}$ & $\$ 2.47 \mathrm{~K}$ & $\$ 98.44 \mathrm{~K}$ \\
& & & & \\
Intangible Assets/Total Assets & 1634 & 0.1900 & 0.1034 & 0.2160 \\
(Int. Assets - Goodwill)/TA & 1622 & 0.0854 & 0.0203 & 0.1451 \\
& & & & \\
Net Income/Total Assets & 1633 & 0.0053 & 0.0427 & 0.5080 \\
EBIT/Total Assets & 1633 & 0.0502 & 0.0806 & 0.4257 \\
& & & & \\
Dividends/Total Assets & 1634 & 0.0223 & 0.0000 & 0.0700 \\
(Div. + Share Repo)/TA & 1457 & 0.0338 & 0.0046 & 0.0941 \\
& & & & 0.1438 \\
Cash/Total Assets & 1625 & 0.1301 & 0.0854 & 0.1438 \\
Cash \& Mkt Sec/Total Assets & 1634 & 0.1684 & 0.1082 & 0.1807 \\
Q ratio & & & & \\
Annual Sales Growth & 1439 & 0.1121 & 0.0470 & 0.4872 \\
Order Backlog/Sales & 424 & 0.3427 & 0.0607 & 1.1166 \\
Annual Employee Growth & 1402 & 0.0401 & 0.0088 & 0.2189 \\
(CAPX-DEP)/Total Assets & 1622 & 0.0115 & 0.0013 & 0.0620 \\
\hline
\end{tabular}

Red indicates a negative coefficient 
We find evidence exempt controlled-firm employ much more long-term debt on their Balance Sheets than non-exempt controlled-firms. However, the long-term capital structure of controlled-firms (LT Debt/Market Value of Equity), whilst lower than non-exempt, the difference is not statistically significant at normal levels. Whilst these means look very different, the denominator is extremely volatile. The use of more long-term debt (based on Balance Sheet ratios) by exempt controlled-firms, with their attendant covenants, may provide the assurance needed to entice independent $5 \%+$ stakeholders to take their significant ownership positions.

We find that on average, exempt controlled-firms engage in much more research \& development (\$ per employee) than non-exempt firms. The mean amount of R\&D 'intensity' ( $\$ R \& D / T o t a l$ Assets) is more than three times the average of the exempt group, although the difference is not significant. Exempt controlled-firms have significantly larger investments in intangible assets. Whether these larger investments are consistent with shareholder wealth maximization is unclear - but they suggest that exempt controlled firms have a longer horizon than (large) non-exempt controlled firms.

As a result of their higher spending, controlled-firms that sought an exemption had significantly larger investments in total intangible assets (standardized by total assets). When one subtracts away the amount of goodwill from the total, you are left with the actual investment in 'intangible' assets. When standardized by total assets, controlled-firms seeking an exemption made significantly larger investments than non-exempt controlled-firms. For example, to capitalize research \& development expenses requires the firm to demonstrate to its auditors that the resulting product is economically viable. The ability to keep these assets on their books suggests that $R \& D$ investments of exempt controlled-firms have been effective.

Over the 10 year period covered by this study, the controlled-firms that sought exemption from the majority independent Director requirement suffered net losses on average - but non-exempt controlled-firms had net profits, on average. The difference in Net Income/Total Assets between the two groups is significant at the $4 \%$ level. The different in EBIT/Total Assets is highly significant (1\% level). Most of the losses experienced by the exempt controlled-firms were during the so-called Great Recession. Whether the exempt controlled-firms were less willing to smooth their earnings than the larger non-exempt controlled-firms is left for future research - but the heavier use of debt and R\&D spending clearly contributed to the lower level of profitability for exempt controlled-firms. The larger frequency and size of reported accounting losses may be a contributing factor to the smaller average market value for the exempt controlled-firms.

Although exempt controlled-firms earned significantly lower profits than controlled-firms that did not seek an exemption, there is no statistical difference in the funds they distributed to their shareholders. Both groups of controlled-firms engaged in about the same level of (net) share repurchases (standardized by total assets) and cash dividends (standardized by total assets) of the exempt group were significantly lower than non-exempt group. Maintaining dividends in the presence of accounting losses could be viewed as value reducing behavior - or it might indicate that the managers are signaling their confidence in the future performance of the firm.

We find that the larger non-exempt firms had larger average investments in cash and significantly larger cash plus marketable securities (standardized by total assets). This suggests a higher degree of caution amongst the non-exempt firms - consistent with their significantly smaller investments in intangible assets and lower R\&D spending. This behavior may be consistent with the supposition that the exempt controlled-firms have a longer horizon than their larger non-exempt counterparts and that they are willing to engage in (slightly) more risky operating policies in pursuit of long-term value.

Whilst we find that there is no significant difference in the average Q ratio for the two groups, we find that the average yearly sales growth is nearly double the sales growth of non-exempt controlled-firms (significant at the $10.4 \%$ level). Although the measures are often missing, we find that the average reported sales backlog (standardized by total revenue) is significantly higher for non-exempt controlled-firms than exempt controlled firms. Even though non-exempt controlled-firms have larger backlogs/less future revenue uncertainty - the body evidence here suggests they remain more conservative than those controlled-firms that seek an exemption.

Exempt controlled-firms engage in more capital spending (standardized by total assets) than non-exempt firms, but the difference is not significant at normal levels $(11.1 \%)$. We subtract depreciation from capital expenditures, producing a 'net growth' in long-term asset. When this measure is positive (negative), net fixed assets on the Balance Sheet will rise (fall). We find that exempt controlled-firms have on average much stronger growth than non-exempt firms (which are basically just replacing their depreciated assets during the period 2005-2014). 
We find evidence that the average efficiency (\$Sales/Employees) of employees at an exempt controlled-firm is higher than the average for non-exempt controlled-firm employees. This is more weak evidence that the higher investment in intangibles and R\&D spending per employee by exempt controlled-firms translates into higher revenues per employee. Unfortunately, these higher revenues did not translate into significantly higher average profits. Lastly we note that exempt controlled-firms grew their payrolls at a slower pace than the larger non-exempt controlled-firms.

Difference in means tests suggest difference in behaviors for controlled-firms - but it is not clear that the opting for an exemption to the majority independent Director listing requirement (which leads to Boards with fewer independent voices) has valuation consequences. We investigate this hypothesis through regression analysis. Firm year observations are excluded if the firm is insolvent (stockholder equity is negative). Regression results for models where the firm's $Q$ ratio is the dependent variable are reported in Table 3.

Table 3. Controlled firms: exempt and non-exempt

Mean performance and policy measures

\begin{tabular}{llllll}
\hline Item & $\mathrm{N}$ & Exempt & Non-Exempt & t-Statistic & Sig. Level \\
\hline Total Assets & 1634 & $\$ 2,803.4 \mathrm{~K}$ & $\$ 3,786.8 \mathrm{~K}$ & -2.519 & .012 \\
Total Revenue & 1643 & $\$ 2,181.9 \mathrm{~K}$ & $\$ 3,495.8 \mathrm{~K}$ & -4.331 & .000 \\
Market Value of Equity & 1594 & $\$ 3,279.5 \mathrm{~K}$ & $\$ 6,974.6 \mathrm{~K}$ & -3.589 & .000 \\
& & & & & \\
LT Debt/Total Assets & 1634 & 0.3427 & 0.1809 & 5.503 & .000 \\
LT Debt/MV Equity & 1593 & 1.4682 & 2.6742 & -0.759 & .448 \\
& & & & & \\
R\&D/Total Assets & 691 & 0.1056 & 0.0300 & 2.165 & .031 \\
R\&D/Employee & 660 & $\$ 32.80 \mathrm{~K}$ & $\$ 11.53 \mathrm{~K}$ & 3.318 & .001 \\
& & & & & \\
Intangible Assets/Total Assets & 1634 & 0.2118 & 0.1410 & 6.237 & .000 \\
(Int. Assets - Goodwill)/TA & 1622 & 0.0959 & 0.0607 & 4.568 & .000 \\
& & & & & \\
Net Income/Total Assets & 1633 & 0.0217 & 0.0346 & -2.090 & .037 \\
EBIT/Total Assets & 1633 & 0.0286 & 0.0962 & -2.983 & .003 \\
& & & & & \\
Dividends/Total Assets & 1634 & 0.0217 & 0.0241 & -0.666 & .506 \\
(Div. + Share Repo)/TA & 1457 & 0.0327 & 0.0367 & -0.752 & .452 \\
& & & & & \\
Cash/Total Assets & 1625 & 0.1269 & 0.1364 & -1.241 & .215 \\
Cash \& Mkt Sec/Total Assets & 1634 & 0.1628 & 0.1807 & -1.860 & .063 \\
& & & & & \\
Q ratio & 1594 & 1.8647 & 1.7687 & 0.381 & .703 \\
Annual Sales Growth & 1439 & 0.1121 & 0.0670 & 1.628 & .104 \\
Order Backlog/Sales & 424 & 0.3427 & 0.5687 & -1.924 & .055 \\
& & & & & \\
CAPX/Total Assets & 1622 & 0.0566 & 0.0505 & 1.595 & .111 \\
(CAPX-DEP)/Total Assets & 1622 & 0.0143 & 0.0058 & 2.539 & .011 \\
& & & & & \\
Sales/Employee & 1577 & $\$ 489.45 \mathrm{~K}$ & $\$ 454.89 \mathrm{~K}$ & 1.066 & .287 \\
Annual Employee Growth & 1402 & 0.0379 & 0.0429 & -0.400 & .689 \\
\hline
\end{tabular}

Red indicates a negative coefficient

The first column reports results obtained when Q ratios are regressed against a set financial policy variables only. The $\mathrm{R}^{2}$ of this model is 0.173 and it is highly significant (F-statistic 39.29). The financial variables are all highly significant and enter the model predictably, for firms that are controlled by an individual or group. Leverage (Total Long-Term Debt divided by Total Assets) is negatively related to Q - consistent with the notion that the market 
penalizes controlled-firm value when they engage in debt financing. A firm with an average Debt/Asset ratio of $25 \%$ would see their $\mathrm{Q}$ ratio reduced by about 20 basis points. Given an average total asset size of about $\$ 3$ billion - each basis translates into roughly $\$ 30$ million in market value - so the average use of debt reduces controlled-firm values by about $\$ 600$ million.

Table 4. Regression results

Dependent variable: Q-ratio*

\begin{tabular}{|c|c|c|c|c|c|c|c|c|c|}
\hline $\mathrm{R}^{2}$ & 0.173 & 0.175 & 0.180 & 0.179 & 0.188 & 0.190 & 0.198 & 0.197 & \\
\hline F-Statistic & $43.85^{3}$ & $37.95^{3}$ & $34.52^{3}$ & $26.67^{3}$ & $22.75^{3}$ & $18.93^{3}$ & $16.66^{3}$ & $25.71^{3}$ & \\
\hline Constant & $0.954^{3}$ & $1.018^{3}$ & $1.077^{3}$ & $1.049^{3}$ & $0.931^{3}$ & $0.791^{3}$ & $0.951^{3}$ & $1.094^{3}$ & \\
\hline DEBT/TA & $0.792^{3}$ & $0.728^{3}$ & $0.718^{3}$ & $0.723^{3}$ & $0.751^{3}$ & $0.759^{3}$ & $0.787^{3}$ & $0.772^{3}$ & \\
\hline CAPX/TA & $2.833^{3}$ & $2.833^{3}$ & $2.886^{3}$ & $2.837^{3}$ & $2.812^{3}$ & $2.825^{3}$ & $2.488^{3}$ & $2.404^{3}$ & \\
\hline INT/TA & & $0.592^{3}$ & $0.632^{3}$ & $0.625^{3}$ & $0.643^{3}$ & $0.652^{3}$ & $0.649^{3}$ & $0.783^{3}$ & $0.746^{3}$ \\
\hline CMS/TA & $2.553^{3}$ & $2.586^{3}$ & $2.562^{3}$ & $2.565^{3}$ & $2.521^{3}$ & $2.501^{3}$ & $2.412^{3}$ & $2.423^{3}$ & \\
\hline DIV/TA & & $2.574^{3}$ & $2.585^{3}$ & $2.632^{3}$ & $2.606^{3}$ & $2.674^{3}$ & $2.671^{3}$ & $2.619^{3}$ & $2.671^{3}$ \\
\hline NI/TA & $0.494^{2}$ & $0.480^{2}$ & $0.395^{1}$ & $0.405^{1}$ & $0.357^{1}$ & 0.372 & $0.399^{1}$ & $0.405^{1}$ & \\
\hline REVGROW & $0.283^{3}$ & $0.291^{3}$ & $0.286^{3}$ & $0.283^{3}$ & $0.306^{3}$ & $0.313^{3}$ & $0.334^{3}$ & $0.327^{3}$ & \\
\hline D1 EXEMPT & & $0.141^{1}$ & $0.137^{1}$ & $0.139^{1}$ & $0.131^{1}$ & 0.117 & 0.102 & & \\
\hline D2 2008\&2009 & & & & $0.237^{3}$ & $0.238^{3}$ & $0.237^{3}$ & $0.234^{3}$ & $0.236^{3}$ & $0.237^{3}$ \\
\hline VOTING \% & & & & 0.001 & 0.001 & 0.002 & 0.002 & & \\
\hline WEDGE \% & & & & 0.001 & $0.003^{1}$ & $0.003^{1}$ & 0.000 & & \\
\hline D3 FAMILY & & & & & $0.285^{3}$ & $0.304^{3}$ & $0.406^{3}$ & $0.440^{3}$ & \\
\hline D4 FOUNDER & & & & & & 0.119 & 0.146 & $0.285^{3}$ & $0.305^{3}$ \\
\hline $\begin{array}{l}\text { D5 } \\
\text { STAKEHOLDER }\end{array}$ & & & & & 0.165 & 0.185 & 0.166 & & \\
\hline D6 CEO INDY & & & & & & & 0.119 & 0.117 & \\
\hline D7 CEO=CHAIR & & & & & & & $0.127^{1}$ & 0.115 & \\
\hline D8 CHAIR INDY & & & & & & & 0.109 & 0.067 & \\
\hline $\begin{array}{l}\text { CONTROL } \\
\text { PAYMENT }\end{array}$ & & & & & & & & $0.221^{3}$ & $0.247^{3}$ \\
\hline $\begin{array}{l}\text { SAGGARED } \\
\text { BOARD }\end{array}$ & & & & & & & & $0.155^{1}$ & $0.159^{1}$ \\
\hline MULTI-CLASS & & & & & & & & $0.230^{2}$ & $0.224^{3}$ \\
\hline
\end{tabular}

*Excluding years when firms were insolvent (stockholder's equity $<\$ 0$ ), $n=1280$

$3,2,1$ superscripts indicate statistical significance at the $1 \%, 5 \%$, and $10 \%$ levels, respectively

Red indicates negative coefficient 
Cash and marketable securities and dividend payouts (both standardized by Total Assets) are also positively related to $\mathrm{Q}$ ratios. The positive relation between cash and marketable securities holdings and $\mathrm{Q}$ ratios is consistent with the relatively conservative behavior expected of controlled-firms. Whilst dividends reduce liquidity, controlled-firms could squander free cash-flows - so dividend distributions (or share repurchases) reduces funds available and enhance $\mathrm{Q}$ ratios.

The second column reports the same group of financials and adds a dummy variable (D1) that takes on the value of one when a controlled-firm seeks a majority independent Director majority exemption (zero for non-exempt). The $\mathrm{R}^{2}$ rises slightly (0.175) and whilst the F-statistic remains high - it falls when compared to the first model. There no change in the pattern or strength of results for the group of financials. We find that D1 is small and negative suggesting a fourteen basis points reduction in the controlled-firm's Q ratio when It applies for an exemption. The exemption dummy is significant at the $6 \%$ level.

The third column adds a dummy variable that takes on the value of 1 for calendar years 2008 and 2009 - the so-called Great Recession. The $\mathrm{R}^{2}$ for this model rose to 0.180 . The fixed year effect is negative and highly significant. Given the tremendous run down in stock prices, it is not surprising to see that the average $Q$ ratio value for firms in our sample lost about 24 basis points. The addition of this variable caused the profitability measure (Net Income/Total Assets) significance level to fall.

The fourth column adds the controlling individual/group's voting and wedge percentages to the list of explanatory variables. Again the $\mathrm{R}^{2}$ actually falls slightly, as does the F-statistic falls. Neither of these variables is statistically significant. It may be that these variables, particularly the wedge factor may (negatively) influence Q ratios when an individual/group has influence (voting control $<50 \%$ ) rather than control.

The fifth column adds three dummies that focus on the identity of the individual/group that has voting control of the firm: a family (D2), the founder (D3), or a stakeholder (D4). This means that the 'base-line' would be exempt-firms that are controlled by another company: a group that Atanasov et al (2010) have shown are often exploited by their parent firm. The $\mathrm{R}^{2}$ of this model rises (to 0.188 ) when compared with the fourth model, but the F-statistic continues to drop. The family-control dummy variable is positive and highly significant - suggesting an increased Q by 28 basis points (v. company controlled firms) and founder-control dummy is positive but not significant.

The sixth column reports results from the model that adds three dummies that focus on the controlled-firm's management: the independence of the CEO (D5), whether the CEO is also the Board Chair (D6), and whether the Board Chair (D7) is independent (of the controlling individual/group). The overall $\mathrm{R}^{2}$ of this model rises to 0.190 (but the F-statistic drops to 18.66). None of the dummy variables enter the model at regular (5\%) significance levels, but all have a positive sign. The results suggest that $\mathrm{Q}$ rises when the Board Chair is also the CEO (significant at the $10 \%$ level).

The seventh column reports results when three dummy variables that measure take-over defenses are added: change in control compensation contract element for CEOs (D7), staggered Board elections (D8), and existence of more than one class of voting securities (D9). This model has the highest $\mathrm{R}^{2}(0.198)$. All of the variables have a negative sign, and all are statistically significant (although the staggered Board election is only significant at the $10 \%$ level). The addition of the take-over defenses information led all three of the management factors to be insignificant, along with the voting and wedge variables. The results suggest that adoption of all three take-over defenses reduces Q-ratios by roughly 63 basis points - about one-third of the sample average $\mathrm{Q}$ ratio or about $\$ 2$ billion.

The eighth and final model eliminates variables until we collapse to the smallest set of highly (1\% level or better with the exception of Net Income/Total Assets, which was significant at the $6.6 \%$ level) statistically significant factors. We are left with six dummies: year (2008 and 2009) fixed effect, the family and founder dummies (as controlling individual/group), and the three take-over defense variables. The management structure variables, the voting and wedge percentages, and the act of opting out of the majority independent Board member listing requirement do not contribute to our understanding of (relative) valuation differences. The $\mathrm{R}^{2}$ of this last model falls only slightly from the seventh and largest model.

\section{Summary of Findings}

This paper focuses on the behavior of firms that are $>50 \%$ controlled by an individual or group. Whilst often discussed in the abstract, very little has been written about these firms. Much of the corporate control literature would suggest that independent shareholders of controlled-firms face an abnormally high risk of wealth expropriating behavior. Our analysis of proxy statement disclosures on insider dealings found less than $1 / 3 \mathrm{rd}$ of firms sampled disclosed any transactions between the firm and the controlling individual/group and none of the 
transactions was economically significant when the amount was standardized by the market value of the firm's equity.

We find no instances that the management structure (broadly defined) of controlled-firms seeking an exemption from the majority independent Director listing requirements of the NYSE and NASDAQ differ from those controlled-firms who opt not to obtain an exemption, with one exception: the proportion of Board seats held by independent Directors. This result is to be expected - it is the reason that the controlled-firm is looking for an exemption. Ironically, on average the majority of seats on exempted controlled-firms are held by directors who are considered independent. Only a very small number of firms (5 out of 173) in our sample take full advantage of their control status and have no independent members on the Board.

The most cited reason for asking for an exemption is the desire to not give up control over the Board nomination process. If one a priori categorized those controlled-firms that seek an exemption as more 'opaque' than controlled-firms that do not seek an exemption, ex-post one would probably be disappointed at how little the behaviors of the two groups differ.

Where differences in means do exist, they seem to be more consistent with the notion that the controlled-firms are engaged in activities with longer-term horizons than non-exempt controlled-firms. Rather than using their 'opaqueness' to hide exploitive behavior, controlled-firms which seek exemptions from the majority independent Director listing requirement seem to seem to be using non-independent directors with firm/industry expertise in conjunction with a long-term strategy to create value for all shareholders. (Note 13) The one exception to this generalization could be if one interprets the dividend distribution practices, conditioned on the knowledge of losses reported by exempt controlled-firms, as exploitative ( $\mathrm{v}$. a signal of management's confidence of their strategies ultimate success).

The regression analysis of $\mathrm{Q}$ ratios suggest that the marketplace penalizes controlled-firms that engage in risky financial behavior (i.e. high debt, low cash balances), but rewards controlled-firms that seem to engage in riskier operating policies (i.e. high capital spending, high creation of intangible assets). The market lowers $\mathrm{Q}$ ratios for firms that seek an exemption from the majority independent Board members listing requirements - but this effect is not statistically significant in the presence of almost any other non-financial factor.

The 'penalty' for seeking an exemption pales in comparison to the reduction in Q ratios that change in control CEO compensation contract features, having staggered Board elections, or having multiple classes of voting securities. The latter is the method by which most of the controlling individuals/group in our sample gain control (a minority own more than $50 \%$ of the voting securities). The marketplace consistently pays more (per dollar of assets) for a family and founder-controlled firm than one controlled by stakeholders, other companies or hedge-funds.

\section{Consequences and Conclusion}

In the wake of a number of accounting scandals as the start of the $21^{\text {st }}$ century, the US Congress, through the SEC, pushed for greater transparency in corporate governance. Specifically, US-listed public firms were required to have a majority of their Board of Directors composed of members deemed to be "independent". However, controlled firms were permitted to seek an exemption from these stock exchange listing requirements.

We find no real evidence that exempted firms behave differently from those controlled firms that have a majority of their Board seats held by independent directors. This isn't a surprise: controlled firms can always sack troublesome independent directors and obtain an exemption. What is surprising is that controlled firm behavior is not exploitative, it is best described as consistent with the stewardship hypothesis. In our opinion, any calls for additional/tighter regulation of controlled firms based on concerns for minority shareholders is not supported by the evidence to date.

\section{References}

Accounting Principles Board (APB). (1971). APB Opinion No. 18: "The Equity Method of Accounting for Investments in Common Stock".

Anderson, R., Duru, A., \& Reeb, D. (2012, June). Investment Policy in family-controlled firms. Journal of Banking and Finance, 36(6), 1744-1758.

Atanasov, V., Boone, A., \& Hasushalter, D. (2010, February). Is There Shareholder Expropriation in the United States? An Analysis of Publicly Traded Subsidiaries. Journal of Financial and Quantitative Analysis, 45(1), $1-26$. 
Berrone, P., Cruz, C., Gomez-Mejia, L., \& Lanzaz-Kintana, M. (2010). Socioemotional Wealth and Corporate Responses to Institutional Pressures: Do Family-Controlled Firms Pollute Less?. Administrative Science Quarterly, 55(1), 82-113.

Carney, M. (2005, May). Corporate Governance and Competitive Advantage in Family-Controlled Firms. Entrepreneurship Theory and Practice, 29(3), 249-265.

Dyer, W. G., \& Whetten, D. A. (2006, November). Family Firms and Social Responsibility: Preliminary Evidence from the S\&P 500. Entrepreneurship Theory and Practice, 30(6), 785-802.

Dudley, R. (2006). Wal-Mart Board Seen at Risk of Losing Independent Voices. BloombergBusiness, June 6.

Financial Accounting Standards Board (FASB). (1987). Statement of Financial Accountings Standard No. 94: "Consolidation of All Majority-Owned Subsidiaries: An Amendment of ARB No. 51 with Related Amendment of APB no. 18 and ARB no. 43," Stamford, CT.

Gomez-Mejia, L. R., Makri, M., \& Larraza-Kintana, M. (2010, March). Diversification Decisions in Family Controlled Firms. Journal of Management Studies, 47(2), 223-252.

Jensen, M., \& Meckling, W. (1976). Theory of the Firm: Managerial Behavior, Agency Costs, and Ownership Structure. Journal of Financial Economics, 3, 305-360.

Lee, J. (2006, June). Family Firm Performance: Further Evidence. Family Business Review, 19(2), 103-114.

McConaughy, D., Walker, M., Henderson, G., \& Mishra, C. (1998). Founding family-controlled firms: efficiency and value. Journal of Corporate Finance, 7(1), 1-19.

McConaughy, D., \& Phillips, M. (1999, June). Founders versus descendants: The profitability, efficiency, growth characteristics, and financing in large public founding-family-controlled firms. Family Business Review, 12(2), 123-131.

New York Stock Exchange Listed Company Manuel, Section 3: Corporate Responsibility. (New York 2003) 303A.02.

Selia-Atmaja, L., Tanewskii, G., \& Skully, M. (2009, September/October). The role of dividends, debt and Board Structure in the Governance of Family Controlled Firms. Journal of Accounting, Business and Finance, 36(7-8), 863-898.

Shyu, Y-W., \& Lee, C. (2009, September). Excess Control Rights and Debt Maturity Structure in Family Controlled Firms. Corporate Governance: An International Review, 17(5), 611-628.

Villalonga, B., \& Amit, R. (2006, May). How Do Family Ownership, Control, and Management Affect Firm Value?. Journal of Financial Economics, 80(2), 385-417.

\section{Notes}

Note 1. Subsequently the NYSE required that the Audit, Compensation, and the Nominating/Corporate Governance committees of the Board should be composed of independent Directors. The NASDAQ requires that the Audit committee consist of independent Directors but are not required to have either a Compensation or Nominating committee. If a NASDAQ listed firm establishes a Compensation or Nominating committee, they must have at least three members and one must be independent.

Note 2. As taken from the NYSE Handbook for member companies "No director qualifies as "independent" unless the board of directors affirmatively determines that the director has no material relationship with the listed company (either directly or as a partner, shareholder or officer of an organization that has a relationship with the company).

(ii) In addition, in affirmatively determining the independence of any director who will serve on the compensation committee of the listed company's board of directors, the board of directors must consider all factors specifically relevant to determining whether a director has a relationship to the listed company which is material to that director's ability to be independent from management in connection with the duties of a compensation committee member, including, but not limited to: (A) the source of compensation of such director, including any consulting, advisory or other compensatory fee paid by the listed company to such director; and (B) whether such director is affiliated with the listed company, a subsidiary of the listed company or an affiliate of a subsidiary of the listed company."

Note 3. As reported by Dudley in June of 2013 the heirs of Sam Walton combined ownership of Walmart exceeded $50 \%$ of the outstanding stock, but the firm has opted not choose exempt status. The heirs share ownership has 
remained relatively constant for over a decade, but their ownership percentage has increased from roughly $39 \%$ to just over $50 \%$ of shares outstanding due to Walmart's common stock repurchasing over $\$ 36 \mathrm{~B}$ of shares on the open market.

Note 4. Whilst the virtual absence of the probability of discipline is generally thought to be a necessary condition for expropriation behavior - it is not a sufficient condition. An analogy might be that simply because one has motive (personal benefit) and opportunity (lack of vigorous independent corporate governance) does not mean that a crime (expropriation) must be committed.

Note 5. See McConaughy, Walker, Henderson and Mishra (1998). The authors find that family controlled firms are more valuable and more efficient when the founder serves as CEO or as Board Chairman with a hired CEO. First-generation succession of son or daughter as CEO are associated with a smaller valuation effect.

Note 6. See Villalonga and Amit (2006). Contrary to the earlier findings of McConaughy, Walker, Henderson and Mishra (1998), they report when descendants serve as CEO firm value is destroyed.

Note 7. For example, at Boston Beer Company which provides the B shares to elect 5 of the 8 seats on the Board of Directors. Jim Koch, the founder, holds $100 \%$ of the B shares. Five of nine Boston Beer Company directors are independent and the firm has not filed for an exemption.

Note 8. For example, Larry Page and Sergey Brin - the co-founders of Google, control $70.2 \%$ of the voting power. However, seven of ten Google directors are independent and the firm has not filed for an exemption.

Note 9. The NBER defined the recession beginning in the December of 2007 and ending in June of 2009, although real GDP did not decline for two consecutive quarters (the 'old' NBER definition of a recession) until the $4^{\text {th }}$ Quarter of 2008. It may be more appropriate to consider the first year of the Great Recession as a financial crisis that was accentuated by the failure of Lehman Brothers in October of 2008. Ultimately this crisis helped cause a downturn in real economic activity in the US and the rest of the world (where the decline was even more severe).

Note 10. As is the case at Apollo Education, where John and Peter Sterling has $100 \%$ voting control by owning 451,789 class B shares whilst 142 million class A shares have no voting power.

Note 11. Defined as not a related to the controlling individual/group or having previously held employment with an organization that the controlling individual/group controlled or managed (as CEO or Board Chair).

Note 12. Non-exempt firms also would be classified as having lower barriers to takeover because of the relative absence of change in control compensation contracts, but it's 'low' compared to what - as by definition, none of the firms in this sample can be taken over without the consent of the individual/group that has $>50 \%$ voting control.

Note 13. Virtually every controlled firm that seeks an exemption from the majority independent Director listing requirement puts forward a justification like this in their proxy statements. 